Mini Review

OOpen Access

D) CrossMark

\title{
Surgical treatment of the first carpometacarpal joint arthritis using a mini external fixation system
}

\section{Purpose}

Evaluation of our primary results from the use of a mini ex-fix system for the treatment of the first carpometacarpal joint arthritis ${ }^{1-3}$ (Figure1).

\section{Method}

We admitted in our clinic 10 patients the last 2 years. 7 females, 3 males, all of them were agriculture workers. The main age 62 was years old (55-72y).

All the patients complained for pain and tenderness to the base of the thumb more than 3 years and presented decrease grip strength. ${ }^{4}$

In all the patients the anaesthesia was axillary block.

After an open debridement of the first carpometacarpal joint (Figure 2) we apply, under x-ray control, a mini ex-fix system ${ }^{3,5}$ (Figure 3).

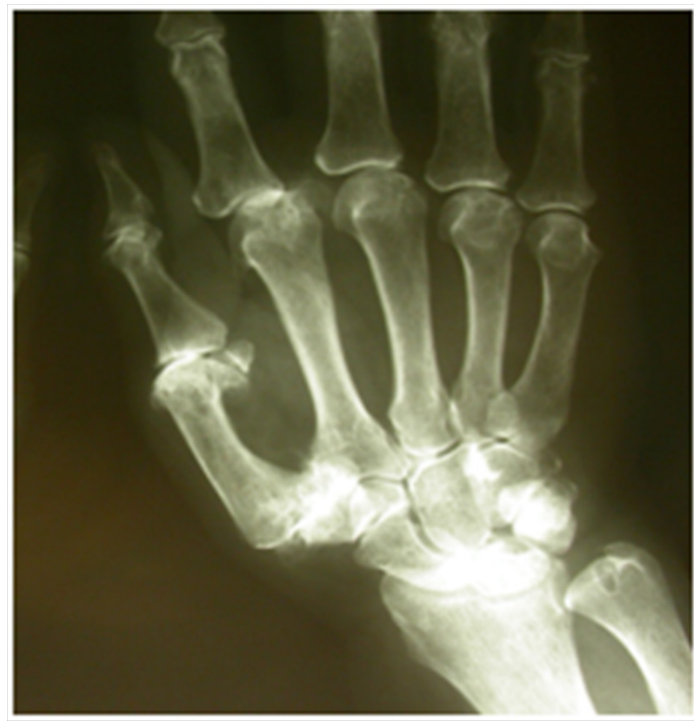

Figure I Mini ex-fix system for the treatment of the first carpometacarpal joint arthritis.

It's very important the application of the first needle of the system to cause compression between the base of the first metacarpal and the trapezium (Figure $4 \& 5$ ). ${ }^{6-10}$

\section{Results}

In all the patients the system was removed after six weeks in outpatient clinic.

One patient had a pin track infection which was treated by oral antibiotics.
Volume 3 Issue 4 - 2015

Athanasios Alexandris, Georgios Varsanis, Nikolaos Tassios, Maria Sfakiotaki,Vaios Goulas

Department of Orthopedics, General Hospital of Trikala, Greece

Correspondence: Athanasios Alexandris, Department of Orthopedics, General Hospital of Trikala, Karditsis 5 I Trikala 42100, Greece, Tel 00306947445950,

Email thalexandris@yahoo.gr

Received: October 14, 2015 | Published: October 27, 2015

The post-op evaluation of the patients includes clinical examination and x-ray control.

All the patients had a short course of physical therapy post-op. ${ }^{11-16}$

All the patients had complete pain relief and most of them returned to their previous activity after 3 months postoperative. ${ }^{17-18}$

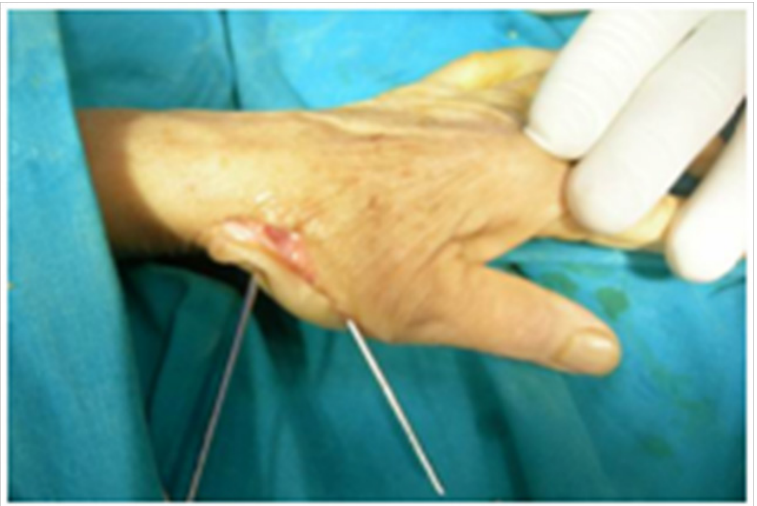

Figure 2 After an open debridement of the first carpometacarpal joint.

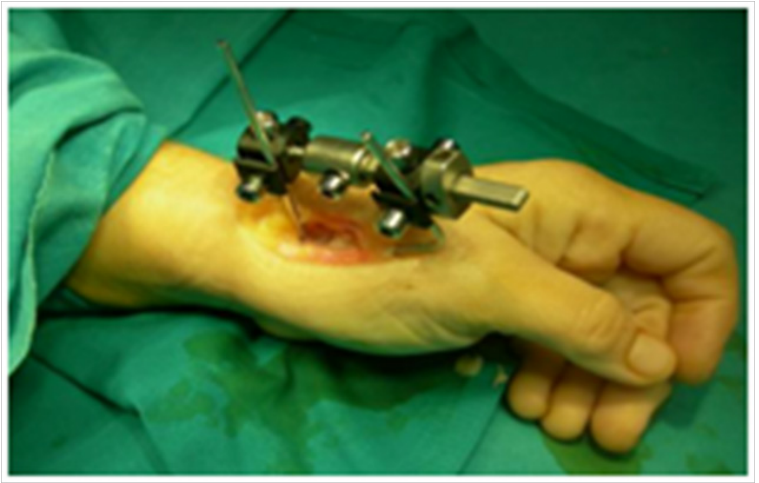

Figure 3 Under x-ray control, a mini ex-fix system. 


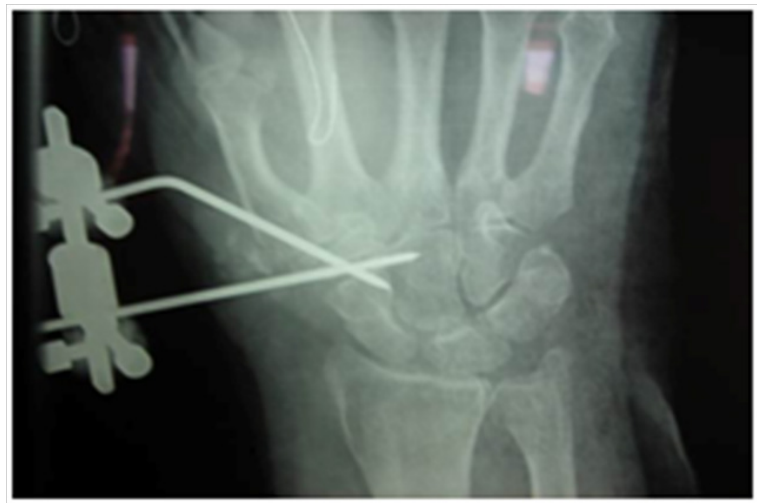

Figure 4 Under x-ray control, a mini ex-fix system.

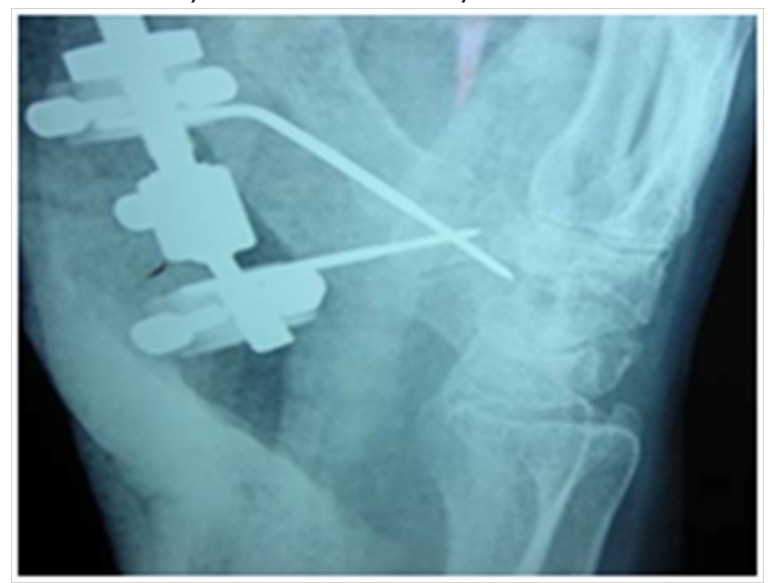

Figure 5 Under x-ray control, a mini ex-fix system.

\section{Conclusion}

Even that the number of the patients and the follow up is short we believe that the above method is a safe and rigid method with satisfactory results (Figure 6). ${ }^{19,20}$

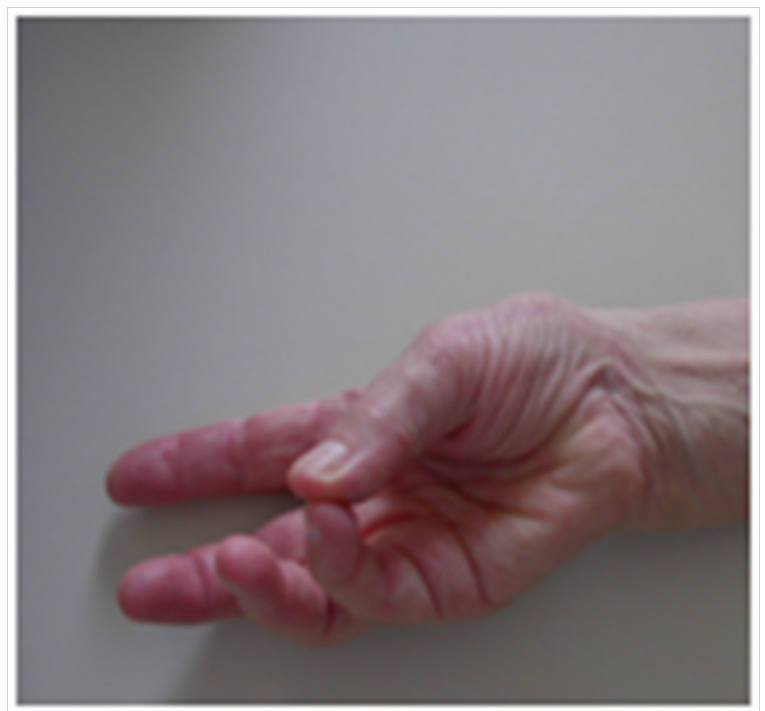

Figure 6 After treatment.

\section{Acknowledgments}

None.

\section{Conflicts of interest}

None.

\section{References}

1. Beckmann J, Rader C, Lüring C, et al. Endoprothetische Gelenkversorgung bei Hüftkopfnekrose. Osteologie. 2010;47-52.

2. Beckmann J, Tingart M, Perlick L, et al. Navigierte Anbohrung der Femurkopfnekrose. Der Orthopäd. 2007;36(5):458-465.

3. Tang TT, Lu B, Yue B, et al. Treatment of osteonecrosis of the femoral head with hBMP-2-gene-modified tissue-engineered bone in goats. $J$ Bone Joint Surg Br. 2008;89(1):127-129.

4. Nickel F, Maierhöfner C. aktuelle Erkenntnisse zur Pathophysiologie des CRPS I. Handchir Mikrochir Plast Chir. 2010;42(1):8-14.

5. Lieberman J, Berry D, Montv M, et al. Osteonecrosis of the Hip: Management in the Twenty-first Century. Instr Course Lect. 2002;52:337-355.

6. Ficat R. Idiopathic Bone Necrosis of the Femoral Head. $J$ Bone Joint Surg B. 1985;67(1):3-9.

7. von Stechow D, Drees P. Operative Therapiekonzepte der Hüftkopfnekrose. Der Orthopäde. 2007;36(5):451-457.

8. Aigner N, Petje G, Schneider W, et al. Bone marrow edema syndrome of the femoral head: treatment with the prostacyclin analogue iloprost vs. Core decompression: an MRI-controlles study. Wien Klin Wochenschr. 2005;117(4):130-135.

9. Symptomatic multifocal osteonecrosis. Amulticenter study. Collaborative Osteonecrosis Group. Clin Orthop Relat Res. 1999;369:312-326.

10. Guerra JJ, Steinberg ME. Distinguishing Transient Osteoporosis from Avascular Necrosis of the Hip. J Bone Joint Surg Am. 1995;77(4):616-624.

11. Min Hong J, Kim TH, Chae SC, et al. Kim S.-Y. Association study of hypoxia inducible factor 1 Alpha (HIF1Alpha) with osteonecrosis of femoral head in a Korean population. OsteoArthritis and Cartilage. 2007;15(6):688-694.

12. Zirong Li. Scientific diagnosis and treatment of femoral head necrosis. Chinese J Reparative and Reconstructive Surgery. 2005;19(9):685-686.

13. Lieberman J, Conduah A, Urist M. Treatment of Osteonecrosis of the Femoral Head with Core Decompression and Human Bone Morphogenetic Protein. Clin Orthop Relat Res. 2004;429:139-145.

14. Petrigliano F, Lieberman J. Osteonecrosis of the hip: novel approaches to evaluation and treatment. Clin Orthop Relat Res. 2007;465:53-62.

15. Yamamoto T, Irisa T, Sugioka Y, et al. Effects of pulse methylprednisolone on bone and marrow tissues: corticosteroid-induced osteonecrosis in rabbits. Arthritis Rheum. 1997;40(11):2055-2064.

16. Intema F, DeGroot J, Elshof B, et al. The canine bilateral groove model of osteoarthritis. J Orthop Res. 2008;26(11):1471-147.

17. Atsumi T, Kuroki Y, Yamano $\mathrm{K}$, et al. Revascularization in Nontraumatic Osteonecrosis of the Femoral Head. Clin Orthop Relat Res. 1996;325:168-173.

18. Sevitt S, Thompson R. The Distribution and Anastomoses of Arteries supplying the Head and Neck of the Femur. $J$ Bone Joint Surg Br. $1965 ; 47: 560-573$.

19. Straub R, Cutolo M. Involvement of the hypothalamic - pituitaryadrenal/gonadal axis and the peripheral nervous system in rheumatoid arthritis: viewpoint based on a systemic pathogenetic role. Arthritis Rheum. 2001;44(3):493-507.

20. Straub R, Wiest R, Strauch U, et al. The role of the sympathetic nervous system in intestinal inflammation. Gut. 2006;55(11):1640-1649. 
21. Straub R, Günzler C, Miller L, et al. Anti- inflammatory cooperativity of corticosteroids and norepinephrine in rheumatoid arthritis synovial tissue in vivo and in vitro. The FASEB J. 2002;16(9):993-1000.

22. Drescher W, Li H, Lundgaard A, et al. Endothelin-1- induced Femoral Head Epiphyseal Artery Constriction is Enhanced by Long- Term Corticosteroid Treatment. J Bone Joint Surg Am. 2006;88(Suppl 3):173-179.
23. Drescher W, Varoga D, Liebs T, et al. Femoral Artery Constriction by Norepinephrine Is Enhanced by Methylprednisolon in a Rat Model, $J$ Bone Joint Surg Am. 2006;88Supp13:162-166. 